Marquette University

e-Publications@Marquette

English Faculty Research and Publications

English, Department of

$1-1-2005$

\title{
Charlotte Dacre's Zofloya: The Gothic Demonization of the Jew
}

Diane Hoeveler

Marquette University, diane.hoeveler@marquette.edu

Accepted version. "Charlotte Dacre's Zofloya: The Gothic Demonization of the Jew," in The Jews and British Romanticism: Politics, Religion, Culture. Ed. Sheila A. Spector. New York: Palgrave-Macmillan, 2005: 165-178. DOI. (C) 2005 Palgrave-Macmillan Publishing. Used with permission. 


\section{CHAPTER \\ CHARLOTTE DACRE'S ZOFLOYA: \\ THE GOTHIC DEMONIZATION OF THE JEW}

Diane Long Hoeveler

In 1769, an odd little chapbook made its appearance in Hull, entitled The Wandering Jew, or, The Shoemaker of Jerusalem: Who Lived When Our Lord and Savior Jesus Christ Was Crucified, and By Him Appointed to Wander Until He Comes Again: With His Discourse With Some Clergymen About the End of the World. ${ }^{\mathrm{i}}$ This anonymous pamphlet was typical of much millenarian propaganda floating around at the time. But in this work, the Wandering Jew informs the Protestant clergymen that "before the End of the World the Jews shall be gathered together from all Parts of the World, and returned to Jerusalem, and live there, and it shall flourish as much as ever, and that they, and all others, shall become Christians, and that Wars shall cease, and the whole World live in Unity with one another" (7-8). The need to believe that the Other, the Jew, would become "one of us" was indeed strong across Europe, and the thinking was that if they could not be converted, then they could always be killed - for their own good, of course.

The legend of Ahasuerus, the Wandering Jew, is, perhaps, one of the most overlooked archetypal figures in the gothic repertoire, overlooked, that is, by Christian literary critics who simply do not easily recognize the codes of anti-Semitism operating in literary texts. Certainly, by the time Eugène Sue published his version of the tale, Le Juif errant (1844-45), the figure was 
well established in gothic texts, but in 1806, when Charlotte Dacre (b. Charlotte King, c. 1772-1825) took up her pen to write Zofloya, or the Moor: A Romance of the Fifteenth Century, ${ }^{\mathrm{ii}}$ the Wandering Jew was more of a floating signifier, suggesting vague political, sexual, and religious anxieties. For instance, Andrew Franklin's The Wandering Jew, or, Love's Masquerade (Drury Lane, 1797), has a fairly light, mocking, and satiric tone. In this work the Jew is presented as motivated by "miscegenation," his intention being to move to London in order to marry a British beauty and produce an heir to whom he can leave his wealth (shades of Dracula). But apart from the figure of the Wandering Jew, the Jew as Satan or the devil was, in fact, a much more established and pernicious trope. Certainly, since the Middle Ages, Jews had been identified with the devil through six specific associations: as the embodiment of the anti-Christ, as a sorcerer, as a poisoner, as a defiler of the sacrament of communion, as a usurer, and as a practitioner of the ritual murder of Christians. ${ }^{\text {iii }}$

In this essay I will argue that the demon and eponymous character Zofloya is not meant by Dacre to be understood as simply a devilish black man, as I have argued elsewhere earlier in Gothic Feminism. ${ }^{\text {iv }}$ In fact, I think that if we take the full religious, cultural, and social contexts into account, not to mention Dacre's personal history, it is more accurate to read Zofloya as a Jew, and an abjected, demonized, and wandering Jew at that. In projecting her Jewishness onto a black devil who takes her anti-heroine over a cliff with him, Dacre symbolically sent her own birthright, her Jewish identity (shameful because of its association with her father, the "Jew King" of London), into the depths, to emerge as a newly purified British matron-mother, an appropriately WASP-y wife for her respectable WASP and Tory husband Nicholas Byrne. ${ }^{\mathrm{V}}$ Dacre would appear, in fact, to have suffered from what Sander L. Gilman more recently has 
called "Jewish self-hatred," and it is the permutations of how that condition is worked out in the novel that will be examined in this essay. ${ }^{\mathrm{vi}}$

It is hardly necessary in a collection of this kind to rehearse all manifestations of anti-Semitism in Britain, but a few are important for placing Zofloya into a fuller cultural context than it has previously received. In 1753, the Jewish Naturalization Bill was decisively rejected in Britain, and actually so unpopular that it was commonly referred to as the "Circumcision bill." The anonymous pamphlet A Modest Apology for the Citizens and Merchants of London, Who Petitioned the House of Commons Against Naturalizing the Jews (London, 1753), argued that “England was a Christian nation, 'founded upon the doctrine of Jesus Christ,' and could not admit these 'crucifiers' without becoming involved in their inherited guilt."vii Further, as Michael Ragussis has argued, “The Jewish Question” became inextricably interwoven with "the heart of English national identity." For Ragussis, the desire to convert Jews to Christianity was part of nineteenth-century Britain's national cause and identity. ${ }^{\text {viii }}$ There were approximately 8,000 Jews in Britain in 1800, but debates about extending their civil rights were met with an overwhelmingly negative response. ${ }^{\text {ix }}$ As James Shapiro has noted, "The English turned to Jewish questions in order to answer English ones."

But from the medieval period, Jews were anathema in Europe, and certainly England was no exception. The reasons for this demonization are complex, but perhaps the most important for an understanding of Zofloya were the associations Jews had with primitive blood rites, such as ritual slaughter of animals (with the suggestion of cannibalism), and circumcision (misunderstood as male menstruation and symbolic castration). Even more unsavory, in what was known as "the blood libel," Jews were accused of defiling the Host and killing Christians and non-Jews whose blood could be used for the Passover seder, as well as for the unnatural 
prolongation of Jewish lives. ${ }^{\mathrm{xi}}$ Because of these residual traces of their supposed religious practices, Jews were coded as socially other and required to announce this otherness in badges worn on their clothing, badges that were mandatory for all members of the Jewish community as early as 1218 in England. ${ }^{\mathrm{xii}}$ As Trachtenberg notes, "with a little ingenuity the Jew badge may be explained altogether as a sign of the Jew's allegiance to the devil, as medieval versifiers ultimately get around to doing" (26). The Jew was clearly associated with the devil in the popular imagination, and in several medieval engravings, Satan is depicted as wearing a Jew badge and shown participating in Jewish financial transactions. Massacres against Jews occurred in Eastern Europe in 1768, causing a large wave of Jews to emigrate to England, where yet more violent attacks on them began to occur. The Aliens Act of 1793 allowed the government to deport many Jews, as well as to place foreigners living in England under surveillance. xiii $^{\text {iij }}$

In addition to their association with the devil, Jews were also thought to be closely tied to the practice of economic blood sucking, as usury was known at this time. Money lending at an interest was a sin for which Catholics could be excommunicated, but Jews represented in their very being this connection between cash and blood, thought to be at the very root of Christ's betrayal (Judas's thirty pieces of silver). Later, Shakespeare's portrait of Shylock (seeking flesh in exchange for lost money) played on this stereotype. The Hebrew word for lending money at an interest was neshekh, also meaning "to bite," and, as Malchow has noted, "there was always a metaphoric vampirism in the traditional image of the Jew as usurer, as bloodsucker" (160). It was not a huge metaphoric leap for the culture to move from notions of Jews as vampiric and literal bloodsuckers to Jews as agents of the devil to Jews as devils.

In 1783, Parliament passed the Irish Naturalization Act, but Jews were specifically excluded from the rights of citizenship, and ironically, they were frequently aligned in the 
popular press with the Irish, who were themselves presented as simians, brutish simpletons, or a lower species of humanity. But the major difference was that Jews were most typically presented as smarter, much more cunning, Svengali-types of criminals. They were also believed to be the degenerate carriers of syphilis or other diseases (certainly this type reaches its apotheosis in Bram Stoker's creation of the vampire Dracula, with his hook nose and high forehead). Ken Gelder has argued that Jews were frequently figured as "nomadic," and hence were difficult to monitor in their movements throughout Britain. For Gelder, the mobility of the foreign Jew actually produced two contradictory attitudes in British citizenry: Jews were seen on one hand as admirable since they accumulated capital, while on the other hand they became sources of national anxiety because "they drained capital by moving it elsewhere." xiv

Jews were also traditionally associated with Cain (the "cursed" wanderer who had killed his brother), and hence were believed to be part of a criminal and conspiratorial group of Christian-killers. The word "cabal" entered the public discourse sometime during the later half of the seventeenth century. The term made its way very early into gothic literature, and Davison has identified the "cabalistic" backdrop of early gothics, stating that we can recognize the cabalistic in the persistence of "the Spanish inquisition, conspiratorial anti-Christian secret societies (or cabals), secret sciences, the violation of familial bonds (e.g. patricide and incest), popular millenarian ideas, and the bastardization and demonic figuration of the Cabala as a dark mirror, or double, of the Christian New Testament" (22). All of these figurations were, according to Davison, precipitated 'by fears that a secular-spiritual 'Apocalypse' like the French Revolution would occur on British soil. Many thought that such a cataclysm would signal the Last Days and would occur as a result of an intricate anti-Christian conspiracy which qualified as Gothic fiction in its own right" (22). Freemasons and Rosicrucians, believed to be controlled by Jacobin-like 
Jews who were scheming to advance their own economic interests, and were thought to be operating at the expense of British national "progress."

In fact, in what we can recognize as a species of "Jewish hysteria," Christians actually began to think that they had become the Wandering Jew. Martin Gardner sees the Wandering Jew impersonations as instigated by a pamphlet published first in Germany in the seventeenth century, in which a Jewish shoemaker named Ahasuerus claimed to be the actual Wanderer. Over the next two centuries, people claiming to be the Jew appeared all over Europe, with one appearing as late as 1868 in Salt Lake City. ${ }^{\mathrm{xvi}}$ In his Curious Myths of the Middle Ages (2 vols., London, 1866), the Reverend Sabine Baring-Gould tells us that "men who were either impostors claiming to be the Wandering Jew, or lunatics who actually believed they were this unhappy man, appeared in England in 1818, 1824, and 1830."xvii

Trachtenberg has argued that the negative portrait of the Wandering Jew began during the medieval period and was very quickly assigned to the entire Jewish population as a whole: "In most of the accounts, the Wandering Jew had forsaken his false faith and adopted the true faith of Jesus, in contrast to the obduracy of his fellow Jews; several versions, however, have him remain a Jew, refusing to acknowledge through baptism the truth to which his own unique career testified, and thus typifying the attitude of all Jews" (17). Further, Trachtenberg observes that “Satan's semitic features are often emphasized with grotesque exaggeration ... [and] Mephistopheles is usually swarthy, hook-nosed, [and] curly-headed" (26). Hyam Maccoby, however, has provided a nuance to our understanding of the Jewish stereotype by observing: "The Jews were never put on the same footing as the other heretics. They were the representatives of the Old Religion, against which Christianity had rebelled, and there was a feeling of bad conscience against them. The Jews were Father-figures, and rebellion against the 
father is never a straightforward expression of hatred" (239). The Jew as devilish father-figure would have been all too familiar to Dacre, whose father was increasingly the source of scandal and embarrassment to her as she attempted to establish herself as both a woman writer and as a respectable wife and mother.

Maccoby also emphasizes the other, Germanic versions of the Wandering Jew, the man who was a purely negative embodiment of defiance in the face of Jesus's sufferings and death. In these darker versions of the figure, the sufferings of the Wandering Jew are seen merely as just punishment for his depravity. He is not a convert to Christianity, but an unregenerate Jew, with evil magic powers derived from his long experience of life and his association with the devil. It was this negative version that gave rise to the nineteenth-century anti-Semitic stereotype, taken up with enthusiasm by the Nazis, of the Jew as a "rootless cosmopolitan" (252). When Dacre presented Zofloya as a black man who by the conclusion of the text reveals himself as the devil, her reading audience would have recognized the many twisted and long-established associations: Zofloya is not simply the devil; he is also a figure of Judaism itself, the old religion that needed to be sent over the edge into the abyss before the newly nationalistic Christian Britain would be safe. Throughout the text, he provides magical powers, sleeping potions, and poisons to Victoria, while conducting mysterious financial dealings. Besides reminding contemporary readers of the devil's associations with Jews, this portrait of Zofloya is also a strange, cryptic, bitter picture of Dacre's own father, the devilish Jew in her own life. 
The final aspects in understanding the use that Dacre makes of the Jewish devil are philosophical, metaphysical, and personal. As Daniel Jonah Goldhagen has observed:

Antisemitisim tells us nothing about Jews, but much about anti-Semites and the culture that breeds them. Even a cursory glance at the qualities and powers that anti-Semites through the ages have ascribed to Jews - supernatural powers, international conspiracies, and the ability to wreck economies; using the blood of Christian children in their rituals, even murdering them for their blood; being in league with the Devil; controlling simultaneously both the levers of international capital and of Bolshevism - indicates that anti-Semitism draws fundamentally on cultural sources that are independent of the Jews' nature and actions, and the Jews themselves then become defined by the culturally derived notions which antisemites project onto them. ${ }^{\text {xiii }}$

Similarly, Jean-Paul Sarte has observed: "It is not the Jewish character that provokes anti-Semitism but, rather, . . it is the anti-Semite who creates the Jew." And further, he has noted that "Far from experience producing [the anti-Semite's] idea of the Jew, it was the latter which explained his experience. If the Jew did not exist, the anti-Semite would invent him.” Julia Kristeva has followed Sartre's lead, stating that the anti-Semites's Jew is an abject "phantasmatic" figure representing ambivalence; he is feared and hated because he does not "respect borders, positions, rules" and "disturbs identity, system, [and] order."xix

But most recently, Sander Gilman has provided a particularly useful way for explaining what Dacre has done by portraying the devil as both Jew and father. For Gilman, "Jewish self-hatred" is caused when Jewish people accept "the mirage of themselves generated by their reference group - that group in society which they see as defining them - as a reality." In order to 
be part of the community and share in that community's identity, the Jew of necessity has to subscribe to "the liberal fantasy that anyone is welcome to share in the power of the reference group if he abides by the rules that define that group. But these rules are the very definition of the Other. The Other comprises precisely those who are not permitted to share power within the society. Thus outsiders hear an answer from their fantasy: Become like us - abandon your difference - and you may be one with us" (2). If we read Zofloya as Dacre's construction of the abjected Jew, then it would appear that he carries symbolic as well as personal freight. Dacre clearly must have heard the siren song of abdicating her Jewish identity and subscribing to her culture's demonization of the Jew when she created Zofloya.

In fact, as Gilman points out, there is also a "conservative curse" to the syndrome of self-hatred: "The more you are like me, the more I know the true value of my power, which you wish to share, [then] the more I am aware that you are but a shoddy counterfeit, an outsider.” The dominant group wishes both to integrate the outsider and yet also to keep him or her at arm's length, and thus "preserve the reification of its power through the presence of the powerless. Thus the liberal promise and the conservative curse exist on both sides of the abyss that divides the outsider from the world of privilege." This contradiction between the "liberal promise" of complete assimilation and the "conservative curse" of perpetual marginalization puts the outsider into what Gilman calls a "classic double bind situation." But outsiders have yet one more possible move: they can "select some fragment of that category in which they have been included and see in that the essence of Otherness, an essence that is separate from their own definition of themselves and [one that] embodies all of the qualities projected onto them by the power group." It would appear that by selecting the most extreme embodiment of the Jew - as Satan, as the devil - Dacre was attempting to abject the ultimate category of otherness within herself. But 
Gilman observes: "for even as one distances oneself from this aspect of oneself, there is always the voice of the power group saying, Under the skin you are really like them anyhow. The fragmentation of identity that results is the articulation of self-hatred" (2-3).

Now, to Dacre's personal history: We know enough about Dacre's father, Jonathan King (1753-1824), to surmise that he would have been an embarrassment to someone as ambitious as Charlotte Dacre. King was one of the most famous Jewish self-made men in London, a banker, a pamphleteer, and a supporter of radical political causes. He was also rumored to have been the lover of Mary Robinson (based on evidence that he had financially blackmailed her); and that was one of the more favorable rumors associated with his name. In 1785, he divorced his first wife, Deborah, the mother of Charlotte and her sister Sophia, in order to marry a countess. He financially supported the defendants in the 1794 Treason Trials, and was the political ally of Charles James Fox and Thomas Paine. By 1798, however, he found himself facing bankruptcy and complete ruin. Most damning, however, were the charges of sodomy and sexual assault brought against him by two prostitutes in July 1798. In rehearsing the sensational claims that the prostitutes made against him, the newspapers of the day asserted that he had beaten his first wife, and that now he was charged with flogging and sodomizing two prostitutes and then offering to pay a small amount of money to hush them up. Not coincidentally, 1798 was the last year that Charlotte published using her father's name. ${ }^{\mathrm{xx}}$

But not only did Dacre want literary fame, she also wanted to marry the Tory editor of the Morning Post, Nicholas Bryne, the man with whom she had already had three children (b. 1806, 1807, and 1809). He, unfortunately, was already married, so they could not marry and baptize their children until 1811, the year his wife died. I would contend, although I admit that I do so solely on the basis of detecting a mass of swirling anxieties in a number of poems and novels, 
that Dacre suffered from a shame of being Jewish (or the Jewish daughter of an almost comically stereotypical Jewish father). Her poem "To the Shade of Mary Robinson" vaguely recalls the rumors that circulated about her father's nefarious blackmail of Robinson, while the other pieces in her Hours of Solitude (1805) suggest that she associated an intense, morbid anxiety with a demon lover-father figure who himself was sexualized in an unnatural, satanic manner.

In addition to marriage and respectability, however, Dacre also wanted to obtain the benefits of full citizenship that her father had written about. In his pamphlet Oppression Deemed No Injustice (1798?), King noted that he suffered from being "alone, isolated and abandoned" after his bankruptcy, and that all Jews were treated as he was, as "beings of another nature, the dignity of humanity is lost." ${ }^{\text {xxi }}$ It is not difficult to see that in Dacre's mind, her father was a doomed, devilish, sexually compromised, financially corrupt Jew. Her portrait of Zofloya is not drawn simply from cultural stereotypes about Jews, but to some extent, must have been drawn from life.

Zofloya, or the Moor (1806) was Charlotte Dacre's second novel, written when she was twenty-four years old (or so she claimed; she was actually thirty-four) and the beautiful toast of London literary circles. Her first novel, The Confessions of the Nun of St. Omer, was written when she was eighteen (read twenty-eight) and in the grip of an infatuation with the excessive gothicism of Lewis's The Monk. By 1809, Dacre's novels were ridiculed as “lovely ROSA's prose" by Byron, who went on to mock the novels as "prose in masquerade, / Whose strains, the faithful echoes of her mind, / Leave wondering comprehension far behind."xxii Despite their improbabilities or more likely because of them, Zofloya was also an early influence on Percy Shelley, whose two youthful gothic novels, Zastrozzi (1810) and St. Irvyne; or The Rosicrucian (1811), bear a number of clear resemblances to Dacre's work. She and her four novels and 
two-volume collection of poetry have been virtually forgotten, except by afficionados of the gothic, but all of these works - most particularly Zofloya - are important historical documents for understanding how literary texts participated in the larger culture's attempt to rewrite appropriate feminine behavior as passionless, passively domestic, and pious. But in creating the character of Zofloya, she also produced a strange act of self-hatred, or perhaps symbolic parricide, creating a black devil who is coded as Jewish, and then purged at the conclusion of the text, much as Dacre changed her name not once, but twice, distancing herself further and further - at least in her own mind - from her notorious Jewish pedigree.

As I have argued elsewhere, Zofloya is racist, xenophobic, and misogynistic - as politically incorrect as any early nineteenth-century text could be. But it is only fair to recognize the anti-Semitism in the novel, also, and given Dacre's parentage and eventual marriage to a WASP, I believe we also need to read the text as one that denigrates and demonizes Dacre's own Jewish origins. And although the action is set in late fifteenth-century Italy, the novel holds up for our view the popular consciousness of bourgeois England, circa 1806. It reveals how thoroughly this society felt besieged by the sexually and financially voracious demands of women and Jews. It reveals that this was a culture looking for someone to blame for the social, familial, political, and economic transformation it was experiencing. It chose to blame the devil-Jew, in league with a sexually demanding woman. This is not an original plot-line, to be sure, but it does epitomize this culture's intense dread of maternal and feminine sexuality as so viciously evil and unnatural that it rivals the blackness of Satan's dark deeds.

Zofloya traces the gothic adventures of Laurina's daughter Victoria, and to a much lesser extent her son Leonardo. Whereas his fall is gradual and tragically familiar within the gothic universe, Victoria's is spectacular and sublimely ridiculous. Consider this scenario. Victoria is 
initially taken by her fallen mother and the mother's adulterous lover Ardolph to an elderly aunt's estate for safe keeping. Ever the opportunist, however, Victoria manages to escape by tricking a female servant into exchanging clothes and then leading her to the edge of the aunt's wooded estate. From there, it is nothing to walk back to Venice where Victoria quickly sets about seducing a rich aristocrat, Berenza, who decides to marry Victoria after she is stabbed trying to defend him against a dagger-wielding assassin. She should have known - the attacker was her own brother Leonardo, who was at this time living with Berenza's former mistress, Megalina Strozzi, a Florentine prostitute. Megalina, like all Italian women in this text, tends to use daggers to settle her scores, and she originally sent Leonardo to kill Berenza, not aware that Berenza would be in bed with Leonardo's sister.

But the action has barely begun. Because Victoria was willing to take a knife in the shoulder for him, she earns the undying love and trust of Berenza. He marries her and they spend the next five years in comparative harmony. But all that is shattered when Berenza's younger and more handsome brother, Henriquez, arrives for a visit. Victoria immediately suffers an intense and lustful infatuation for him, but he finds her repulsive. Indeed, on at least two occasions, he describes her as odious because she is "masculine" (190). Henriquez, instead, is enamored of his lovely little thirteen-year-old orphaned friend, Lilla, thrown into his protection by the deaths of both her parents. Lilla is as blonde as Victoria is dark. Lilla is as pre-pubescent, passive, good and obedient as Victoria is the opposite. Lilla, in other words, is the new bourgeois ideal of the "civilized" domestic idol, the professionally feminine girl-woman, and her murder by Victoria would have been understood by Dacre's contemporaries as mimicking the Jewish ritual murder of a young Christian for sacrificial demon-worship. Victoria embodies the earlier, uncivilized, 
aristocratic woman - vain, lustful, aggressive, actively and openly sexual, violent - but she also increasingly takes on Jewish characteristics that were associated with the devil.

Before we move to Lilla's murder scene, however, it is necessary to examine the other protagonist in the novel - Zofloya, or the Moor - the titular and presumably the most important character in the work. Zofloya is initially presented to us as Henriquez's black servant, acquired in Spain after Zofloya's master was killed in a battle. Matthew Lewis had portrayed a powerful and vengeful black servant named Hassan, in his gothic drama The Castle Spectre (1798), and he had chosen to use Hassan to embody the dualistic characteristics that blacks (and, we might add, Italian women in gothic novels) were thought to possess: a superficial eagerness to please, combined with a tendency, when injured, to plot a violent and extreme revenge. As in Matthew Lewis's Journal of a Residence among the Negroes in the West Indies, about visits to his own Jamaican plantation, the gothic drama presents black slaves only too quick to flip the master-slave dialectic and deal in voodoo-Obeah and slave uprisings. Sensational press accounts of the maroon wars of the 1790s in Jamaica and the bloody revolution in Haiti made the issue all too immediate to ignore.

Significantly, when Hassan swears that he will have his vengeance, he uses language that implies the sexual threat implicit in his very presence in this society: “"Am I not branded with scorn? am I not now despised? What man would accept the negro's friendship? What woman would not turn from the negro in disgust? Oh! how it joys me when the white man suffers!'” (196). Dacre responded to Hassan's query by creating a white woman who embraces the negro or the Jew- and gains supernatural powers by doing so. By the conclusion of the novel, Victoria and Zofloya are living together as lovers, Zofloya having first appeared to Victoria in her dreams the night she met Henriquez and decided that she must sexually possess Henriquez or die. 
Victoria's dreams, which occur throughout the novel, always accurately present the next major action of the text.

Dreams in Dacre's work, however, also suggest a new level of psychological sophistication we have not seen before in the gothic. Victoria's dreams present us with the possibility that the character we recognize as "Zofloya" is actually less a real personage than the dark, demonic, Jewish forces within Victoria's own psyche, her abjected Jewishness. The confluence here of the sexually predatory woman, the Jewish devil, and the black male servant is revealing for what it says about early nineteenth-century British attitudes toward gender, religion, and race. A woman who would sexually pursue not simply one, but two men - and brothers, at that - is a woman who has to be full of the devil. And the devil is not simply represented as black, lower class and foreign; he is literally empowered by functioning in league, as one, with the Jew, as well as with a corrupt aristocratic and foreign woman. The farcical elements of the novel revolve around the unlikely alliance of the hyperbolically white Victoria and her very black and demonic ally and lover, the Jewish devil Zofloya. The menace inherent in the text, however, is not simply the menace of white women taking black or Jewish men as illicit lovers. The deeper threat would appear to be the social and economic alliance of dispossessed populations working together, recognizing their mutual alienation and objectification, and banding as one in a maniacal and deadly pursuit of the great white father and his property. In her alliance with Zofloya, Victoria projects/rejects her demonic Jewishness only to re-incorporate it back within herself. That is, she becomes the poisoner, the magician, and the murderer of young blonde Christian innocence by incorporating within herself the devil Jew's powers, the very powers she despised in her father. 
Victoria uses magical powers gained through her association with the devil/Jew Zofloya to poison her husband, seduce Henriquez, and then cause Henriquez's suicide. After accomplishing these dire deeds with the obliging assistance of Zofloya, Victoria then stalks her real prey, the orphan Lilla, whom Zofloya has left chained and defenseless in the stone cave. The confrontation between the two women is one of the most bizarre in the history of female gothic fiction, almost campy in its self-conscious and hyperbolic posturings, coded in stereotypical gendered terms, loaded with representations of an intermingling of feminine sexuality and perversity. When Victoria descends on the innocent Lilla, she finds Lilla sleeping on the floor of the cave, surrounded by "coarse fragments of scanty food" and clothed only in "a mantle of leopard skin, brought her by Zofloya." The leopard skin, so incongruous in fifteenth-century Italy, tropes the descent this very civilized domestic paragon has made into the animal (or black, passionate) realm: "Upon awakening, Lilla clasps her thin hands upon her polished bosom, and with some of her long tresses, still in pure unaltered modesty, essaying to veil it, she raised her eyes, of heavenly blue, to the stern and frantic countenance of her gloomy persecutor, appearing, in figure, grace, and attitude, a miniature semblance of the Medicean Venus" (218). Lilla here is presented as a virtual Christian icon, a statue of a secularized Virgin Mary, "polished," a "Medicean Venus," while at the same time, she is represented as the embodiment of domestic virtues and characteristics: modest, blue eyes, long blonde hair. Her iconic, fetishistic qualities are further accentuated as she begs Victoria not to murder her. And the fact that Lilla is killed, not by a corrupt monk or a greedy usurping uncle, but by a lustful, vengeful and passionate aristocratic woman, suggests that by 1806 , the female gothic genre had shifted sufficiently to present women as inveterate enemies of each other. But Victoria is not simply a woman; she is 
the reincarnation of the Jewish devil herself, sacrificing young, innocent Christian blood in order to commit unspeakable ritual acts of Satanic (read Jewish) worship.

Victoria drags her victim to the top of a cliff, leaving Lilla's "blood red traces at every step," and announces that she will "push thee headlong" because "no art could root [thee] from the breast of Henriquez." Terrified by the view, Lilla makes her next appeal to Victoria, the sentimental one: “Oh, sweet Victoria, remember we have been friends. - I loved thee! nay, even now I love thee, and believe that thou art mad! - Oh, think, think we have been companions, bedfellows!" (219). Bedfellows? Somehow, one cannot imagine any reason why Victoria would have crawled into bed with Lilla. This appeal to the cult of female friendship is scornfully rejected by Victoria, who now announces to Lilla that Henriquez is dead.

Lilla now makes her final appeal to Victoria. She asks to be killed the same way Henriquez was, by a stiletto through the heart, and to this Victoria agrees. The first plunge wounds "only her uplifted hand, and glanc[es] across her alabaster shoulder, the blood that issued thence, slightly tinged her flaxen tresses with a brilliant red" (220). As much is made of Lilla's shed blood as is made of her blonde tresses. The imagistic mingling here of the two is significant as a representation of soiled innocence. The horror of the scene has to be located in its unnaturalness, the violent murder of one woman by another. And again, we are reminded of a nightmare of Jews feeding voraciously on the flesh of young, idealized, innocent Christian flesh.

But by the conclusion of the novel, Victoria has no hope of escaping the consequences of her many crimes. Her husband's body, which Zofloya had hidden in an old casket in a deserted wing of the castle, has been discovered, as has Henriquez's. Victoria has no choice but to beg protection from Zofloya, who now makes her his mistress. Dacre's sexual and racial nausea can barely be concealed, as the two lovers find themselves living in wanton abandon in the Italian 
mountains with a band of banditti, led by Victoria's brother Leonardo and his dark mistress Megalena. To make the dysfunctional family circle complete, Laurina and Ardolph suddenly arrive as captives, and Leonardo quickly murders Ardolph in retaliation for Ardolph's beatings of Laurina, Leonardo's dying mother. Certainly memories of a man beating his wife would have had a particularly pertinent resonance for Dacre, who once more positions her father's crimes front and center in the text.

We are now told that the only earthly authorities feared by Victoria are the Venetian council of ten, Il Consiglio de Dieci, the powers of the Roman Catholic Church as represented by the Inquisition. Whenever Zofloya wants to threaten or intimidate Victoria, he refers to the "familiars of the holy inquisition," and Il Consiglio is the one legal force against which he could never protect or shield Victoria. Clearly, Dacre's readers would have recognized this aspect of Zofloya as devil/Jew in the Jew's traditional association with the cabal, or a secret society intending to plot the overthrow of Christianity. Even the devil (read Jew), it would appear, hesitates to tangle with the Inquisition. But more significantly, Dacre surely must have known that the Inquisition was blatantly anti-Semitic, forcing Iberian Jews to choose between conversion and death. Historically, the Anglo-Jewish community was founded by Iberian Jews fleeing the Inquisition. Of course, these very forces descend on the mountainous hideout, and Leonardo and Megalena both kill themselves rather than risk being taken alive. Once again, Victoria asks Zofloya to save her, and this time, he announces that he can only do so if she will travel with him to his abode, hell. He strips away the appearance he has assumed on earth, and appears before her as he actually is: "a figure, fierce, gigantic, and hideous to behold! - Terror and despair seized the soul of Victoria; she shrieked, and would have fallen from the dizzying height, had not his hand, who appeared Zofloya no longer, seized her with a grasp of iron by the 
neck!" (254). Racism demanded a demonization of difference, and, as Malchow has suggested, the gothic offered "a language that could be appropriated, consciously or not, by racists in a powerful and obsessively reiterated evocation of terror, disgust, and alienation. But the gothic literary sensibility itself also evoked in the context of an expanding experience of cultural conflict, of the brutal progress of European nationalism and imperialism, and was in part a construct of that phenomenon" (3).

But anti-Semitism also demands a demonization of difference, and this we can see when Victoria quite literally goes to the devil. The moral which Dacre pens on her last page makes her mother's guilt and responsibility for all this clear: "Over their passions and their weaknesses, mortals cannot keep a curb too strong. ... Either we must suppose that the love of evil is born with us (which would be an insult to the Deity), or we must attribute them (as appears more consonant with reason) to the suggestions of infernal influence" (254-55). If the devil is an active presence in the world, then the Jew is its manifestation in the public sphere.

Finally, Victoria embodies Dacre's worst imagining of herself as a Jewish woman descended from a Jewish father who eerily resembled her culture's worst stereotype of a Jew. Victoria is also the representation of every vice that bourgeois Britain found itself repulsed by in Jews. Victoria is the excessive aristocratic woman who has finally waged open war on bourgeois values and received her just punishment, but she also can be read as the devilish Jew, the poisoning, conspiring, murdering force who threatened Britain as it attempted to move toward a new national identity as bourgeois, anti-French, and Protestant. 




\section{WORKS CITED}

Anderson, G. K. The Legend of the Wandering Jew. Providence, RI: Brown University Press, 1965.

-----. "Popular Survivals of the Wandering Jew in England." Journal of English and German Philology 46 (1947), 367-82. Reprint, in The Wandering Jew: Essays in the Interpretation of a Christian Legend, ed. Galit Hasan-Rokem and Alan Dundes, 76-104. Bloomington: Indiana University Press, 1986.

Baring-Gould, Sabine. Curious Myths of the Middle Ages. Edited by Edward Hardy. London: Jupiter, 1977.

Byron, George Gordon. English Bards and Scotch Reviewers. In The Poems of Lord Byron. Edited by Jerome McGann. Oxford: Oxford University Press, 1980.

Cohen, Derek. "Constructing the Contradiction: Anthony Trollope's The Way We Live Now." In Jewish Presences in English Literature, ed. Derek Cohen and Deborah Heller, 61-75. Montreal: McGill, 1990.

Cohen, Derek and Deborah Heller, eds. Jewish Presences in English Literature. Montreal: McGill, 1990.

Craciun, Adriana. Fatal Women of Romanticism. Cambridge: Cambridge University Press, 2003.

Dacre, Charlotte. Hours of Solitude. A Collection of original Poems, now first published. 1805. 2 vols. in 1. New York: Garland, 1978. 
------. Zofloya, or the Moor: A Romance of the Fifteenth Century. Edited by Adriana Craciun. Ontario: Broadview, 1997.

Davison, Carol Margaret. "Gothic Cabala: The Anti-Semitic Spectropoetics of British Gothic Literature.” Ph.D. diss., 1997. [McGill U, Montreal]

Derrida, Jacques. Specters of Marx: The State of the Debt, the Work of Mourning, and the New International. Translated Peggy Kamuf. New York: Routledge, 1994.

Endelman, Todd M. "The Checkered Career of 'Jew' King: A Study in Late Eighteenth-Century Anglo-Jewish Social History." AJS Review 7/8 ( 1983): 69-100.

----. The Jews of Britain: 1656-2000. Berkeley: University of California Press, 2002.

----. The Jews of Georgian England, 1714-1830: Tradition and Change in a Liberal Society. Philadelphia: The Jewish Publication Society of America, 1979. Reprint, with a new preface, Ann Arbor: University of Michigan Press, 1999.

Felsenstein, Frank. Anti-Semitic Stereotypes: A Paradigm of Otherness in English Popular Culture, 1666-1938. Baltimore: The Johns Hopkins University Press, 1995.

Gardner, Martin. “The Wandering Jew and the Second Coming.” Free Inquiry 15 (1995): 32.

Gelder, Ken. Reading the Vampire. London: Routledge, 1994.

Gilman, Sander L. Jewish Self-Hatred: Anti-Semitism and the Hidden Language of the Jews. Baltimore: The Johns Hopkins University Press, 1986.

Goldhagen, Daniel Jonah. Hitler's Willing Executioners: Ordinary Germans and the Holocaust. New York: Knopf, 1996.

Hasan-Rokem, Galit and Alan Dundes, ed. The Wandering Jew: Essays in the Interpretation of a Christian Legend. Bloomington: Indiana University Press, 1986. 
Hoeveler, Diane Long. Gothic Feminism: The Professionalization of Gender from Charlotte Smith to the Brontës. University Park: Penn State Press, 1998.

Katz, Jacob. From Prejudice to Destruction: Anti-Semitism, 1700-1933. Cambridge: Harvard University Press, 1980.

Kristeva, Julia. Powers of Horror: An Essay on Abjection. Translated by Louis A. Roudiez. New York: Columbia University Press, 1980.

Maccoby, Hyam. “The Wandering Jew as Sacred Executioner.” In The Wandering Jew: Essays in the Interpretation of a Christian Legend, ed. Galit Hasan-Rokem and Alan Dundes, 236-60. Bloomington: Indiana University Press, 1986.

Malchow, H. L. Gothic Images of Race in Nineteenth-Century Britain. Stanford: Stanford University Press, 1996.

Michisaw, Kim Ian. “Charlotte Dacre's Postcolonial Moor.” In Empire and the Gothic: The Politics of Genre, ed. Andrew Smith and William Hughes, 35-55. New York: Palgrave/Macmillan, 2003.

Perry, Thomas W. Public Opinion, Propaganda, and Politics in Eighteenth-Century England: A Study of the Jew Bill of 1753. Cambridge: Harvard University Press, 1962.

Ragussis, Michael. Figures of Conversion: "The Jewish Question" and English National Identity. Durham, NC: Duke University Press, 1995.

Schuchard, Marsha Keith. Restoring the Temple of Vision: Cabalistic Freemasonry and Stuart Culture. Leiden: Brill, 2002.

Shapiro, James. Shakespeare and the Jews. New York: Columbia University Press, 1996. 
Singer, Alan H. “Great Britain or Judea Nova? National Identity, Property, and the Jewish Naturalization Controversy of 1753." In British Romanticism and the Jews: History, Culture, Literature, ed. Sheila A. Spector, 19-36. New York: Palgrave/Macmillan, 2002. Rosenberg, Edgar. From Shylock to Svengali: Jewish Stereotypes in English Fiction. Stanford: Stanford University Press, 1960.

Sartre, Jean-Paul. Anti-Semite and Jew. Translated by George J. Becker. 1948; New York: Schoken, 1965.

Trachtenberg, Joshua. The Devil and the Jews: The Medieval Conception of the Jew and Its Relation to Modern Anti-Semitism. New Haven: Yale University Press, 1943.

The Wandering Jew, or, The Shoemaker of Jerusalem: Who Lived When Our Lord and Savior Jesus Christ Was Crucified, and By Him Appointed to Wander Until He Comes Again: With His Discourse With Some Clergymen About the End of the World. In A chap-book, containing the Hull version of the Wandering Jew legend. Hull: John Pitts, 1769. Rpt. Wandering Jew. A chap-book, containing The Hull Version of the Wandering Jew Legend. London: John Pitts, 1800-1809?

i. The Wandering Jew, or, The Shoemaker of Jerusalem: Who Lived When Our Lord and Savior Jesus Christ Was Crucified, and By Him Appointed to Wander Until He Comes Again: With His Discourse With Some Clergymen About the End of the World (Hull, 1767; rpt.. Wandering/ew.A chap-book, containing The Hull Version of the Wandering Jew Legend [London: John Pitts, 1800-1809?]). For an 
historical overview of the trope, see G. K. Anderson, The Legend of the Wandering Jew (Providence, RI: Brown University Press, 1965), as well as his earlier "Popular Survivals of the Wandering Jew in England," Journal of English and German Philology, 46 (1947), 367-82, rpt. in The Wandering Jew: Essays in the Interpretation of a Christian Legend, ed. Galit Hasan-Rokem and Alan Dundes (Bloomington: Indiana University Press, 1986), 76-104, which specifically discusses the Hull chapbook, pp. 84-85. More recently, Frank Felsenstein includes a chapter on the wandering Jew in Anti-Semitic Stereotypes: A Paradigm of Otherness in English Popular Culture, 1666-1938 (Baltimore: The Johns Hopkins University Press, 1995), see chapter 4, “Wandering Jews, Vagabond Jews" (58-90).

ii. Ed. Adriana Craciun (Ontario: Broadview, 1997), 190. All quotations from the novel are from this edition, with page numbers in parentheses.

iii. Joshua Trachtenberg, The Devil and the Jews: The Medieval Conception of the Jew and Its Relation to Modern Anti-Semitism (New Haven: Yale University Press, 1943), 215. Jacob Katz carries the investigation to the present in From Prejudice to Destruction: Anti-Semitism, 1700-1933 (Cambridge: Harvard University Press, 1980).

iv. See Diane Long Hoeveler, Gothic Feminism: The Professionalization of Gender from Charlotte Smith to the Brontës (University Park: Penn State Press, 1998), 143-58. Recently, Kim Ian Michisaw has argued that Dacre's intent in Zofloya is to "restore the dignity, self-worth and culture to the African" in contrast to “abolitionism's pathetic, dying negro.” Michisaw specifically sees Dacre presenting Zofloya the Moor not as Satan, but as the "conquering African," and in his allegiance with Victoria, "the domesticated woman," the two represent a 
particularly frightening and culturally anxious duo: the nubile woman in league with the “enslaved African” (52). See his "Charlotte Dacre’s Postcolonial Moor," in Empire and the Gothic: The Politics of Genre, ed. Andrew Smith and William Hughes (New York: Palgrave, 2003), 35-55.

v. On King, see Todd M. Endelman, “The Checkered Career of 'Jew' King: A Study in Late Eighteenth-Century Anglo-Jewish Social History," AJS Review 7/8 ( 1983): 69-100.

vi. Jewish Self-Hatred: Anti-Semitism and the Hidden Language of the Jews (Baltimore: The Johns Hopkins University Press, 1986), passim.

vii. Thomas W. Perry, Public Opinion, Propaganda, and Politics in Eighteenth-Century England: A Study of the Jew Bill of 1753 (Cambridge: Harvard University Press, 1962), 92-93. More recently, in "Great Britain or Judea Nova? National Identity, Property, and the Jewish Naturalization Controversy of 1753," Alan H. Singer has placed the "Jew Bill” into its broader historical context (in British Romanticism and the Jews: History, Culture, Literature, ed. Sheila A. Spector [New York: Palgrave/Macmillan, 2002], 19-36). In From Shylock to Svengali: Jewish Stereotypes in English Fiction (Stanford: Stanford University Press, 1960), Edgar Rosenberg claims that "each age recreates the Wandering Jew in its own image" (188). By examining the use to which the Wandering Jew is put in literature, he claims, we can "answer the purposes of literary history more readily ... [than the general representations of the Jew for] it changes[,] ... adapts itself to the demands of diverse generations and diverse beliefs[, and] ... provides a more reliable and more 'readable' barometer than Shylock to the kind of civilization, ideology, and regnant literary convention in which it flourishes" (188). Further, he states, "The history of 
Ahasuerus in the period between the appearance of Matthew Gregory Lewis's The Monk in 1796 and the publication of Trilby in 1894 is largely the story of his translation from a religious figure of whom Christ made an example for the edification of other sinners, to a black magician whose sorcery was interesting on secular grounds" (206).

viii. Michael Ragussis, Figures of Conversion: "The Jewish Question" and English National Identity (Durham, NC: Duke University Press, 1995), 188. Also, see Trachtenberg, passim; and H. L. Malchow, Gothic Images of Race in Nineteenth-Century Britain (Stanford: Stanford University Press, 1996).

ix. Derek Cohen, "Constructing the Contradiction: Anthony Trollope's The Way We Live Now," in Jewish Presences in English Literature, ed. Derek Cohen and Deborah Heller (Montreal: McGill, 1990), 62. The most recent study of Anglo-Jewish history is Todd M. Endelmann's The Jews of Britain: 1656-2000 (Berkeley: University of California Press, 2002). On the Romantic Period in particular, see his The Jews of Georgian England, 1714-1830: Tradition and Change in a Liberal Society (Philadelphia: The Jewish Publication Society of America, 1979;.rpt., with a new preface, Ann Arbor: University of Michigan Press, 1999).

x. James Shapiro, Shakespeare and the Jews (New York: Columbia University Press, 1996), 1.

xi. Trachtenberg, 215.

xii. Trachtenberg, 116.

xiii. Carol Margaret Davison, "Gothic Cabala: The Anti-Semitic Spectropoetics of British Gothic Literature" (Ph.D. diss., 1997), 21. [McGill U, Montreal] 
xiv. Reading the Vampire (London: Routledge, 1994), 14.

xv. The most recent history of Freemasonry is Marsha Keith Schuchard's Restoring the Temple of Vision: Cabalistic Freemasonry and Stuart Culture (Leiden: Brill, 2002).

xvi. "The Wandering Jew and the Second Coming," Free Inquiry 15 (1995): 32. For further information, see Hyam Maccoby, “The Wandering Jew as Sacred Executioner," in The Wandering Jew: Essays in the Interpretation of a Christian Legend, ed. Galit Hasan-Rokem and Alan Dundes (Bloomington: Indiana University Press, 1986), 236-60.

xvii. Ed. Edward Hardy (London: Jupiter, 1977), 25.

xviii. Hitler's Willing Executioners: Ordinary Germans and the Holocaust (New York: Knopf, 1996), 39.

xix. Jean-Paul Sarte, Anti-Semite and Jew, trans. George J. Becker (1948; New York: Schocken, 1965), 143, 13; Julia Kristeva, Powers of Horror: An Essay on Abjection, trans. Louis A. Roudiez. (New York: Columbia University Press, 1980), 180, 4. In a very similar move, Jacques Derrida, in Specters of Marx: The State of the Debt, the Work of Mourning, and the New International, discusses what he calls Marx's rhetorical "spectropoetics," his obsession with ghosts, specters and spirits. Derrida defines the spectre as "among other things, what one imagines, what one thinks one sees and which one projects - on an imaginary screen where there is nothing to see" (trans. Peggy Kamuf [New York: Routledge, 1994], 100-101).

xx. The best biographical source for the facts of Dacre's life can be found in Adriana Craciun, Fatal Women of Romanticism (Cambridge: Cambridge University Press, 2003), 111-12. 
xxi. Craciun, 60.

xxii. English Bards and Scotch Reviewers, in The Poems of Lord Byron, ed. Jerome McGann (Oxford: Oxford University Press, 1980), 1:756-58. 